\title{
ERRORS IN SHORT-TERM ABLATION MEASUREMENTS ON MELTING ICE SURFACES
}

\author{
By Fritz Müller and Charles M. Keeler* \\ (Faculty of Graduate Studies and Research, McGill University, Montreal, Quebec, Canada)
}

\begin{abstract}
Rapid changes in time and space in the micro-relief of an ablating glacier surface and radiation-induced melt within the uppermost ice layer, termed the "weathering crust", seriously affect the accuracy of the short-term ablation measurements. The various measuring techniques commonly used (stakes, ablatometers, ablatographs) and some new methods (measurement of discharge from a small supraglacial drainage basin, and mass loss directly measured on core samples) are critically reviewed and assessed in the light of these phenomena. The implications for studies of heat and mass balance are discussed.

It appears that the direct measurement of mass flux is the most accurate means of assessing short-term ablation rates. The errors in short-term ablation measurements by any method are largely compensatory and consequently do not influence long-period mass-balance estimates.
\end{abstract}

RÉsumé. Erreurs des mesures d'ablation à court terme de la surface de glace en fonte. Des changements rapides dans le temps et l'espace du micro-relief de la surface d'un glacier soumise à l'ablation et la fusion due à la radiation dans la croûte superficielle de la glace, affecte sérieusement la précision des mesures d'ablation à court terme. Les techniques variées utilisées communément (balises, ablatomètres, ablatographes) et quelques méthodes nouvelles (mesure du débit d'un petit bassin de drainage superficiel, et perte de masse mesurée directement sur des carottes) sont revues d'une manière critique à la lumière de ces phénomènes. Les implications pour les études d'énergie et de masse sont discutées.

Il apparaît que la mesure directe du flux de masse est le moyen le plus précis pour éviter l'effet de mesures à court terme de la vitesse d'ablation. Les erreurs de mesures d'ablation à court terme pour chaque méthode se compensent largement et en conséquence n'influence pas les timations du bilan de masse pour une longue période d'observation.

Zusammenfassung. Fehler in kurzfristigen Ablationsmessungen auf schmelzenden Eisoberfächen. Rasche Formänderungen im Kleinrelief einer schmelzenden Gletscheroberfläche und strahlungsbedingtes Schmelzen innerhalb der oberflächennahen Schicht, der sog. "Verwitterungskruste", beeinflussen die Genauigkeit kurzfristiger Ablationsmessungen beträchtlich. Die verschiedenen herkömmlichen Messmethoden (Ablationsstangen, Ablatometer oder Ablatographen) und einige neuere Verfahren (Abflussmessungen am Ausgang eines kleinen Einzugsgebietes der Gletscheroberfläche, und direkte Massenverlustbestimmungen an Bohrproben) werden kritisch besprochen und unter spezieller Berücksichtigung der oben genannten Phänomene bewertet. Die Bedeutung der Ergebnisse für Wärme- und Massenhaushaltsstudien wird diskutiert.

Es scheint, dass direkte Massenverlustmessungen die besten kurzfristigen Ablationsdaten liefern. Die Fehler in beliebigen kurzfristigen Ablationsmessungen kompensieren sich grösstenteils und haben daher keinen Einfluss auf langfristige Massenhaushaltsberechnungen.

\section{INTRODUGTION}

The chief aim of glacial meteorology is to determine the relationship between the prevailing meteorological situation and the behaviour of glaciers. An important and widely studied aspect of glacial meteorology is the energy balance at melting ice surfaces. Such studies have attempted to determine the important factors in the ablation of ice.

It is common practice in energy-balance studies on melting ice surfaces to compare the heat input with ablation, usually measured by observing changes in surface level relative to some fixed reference. In some cases measured ablation has been used as a known quantity in the computation of the energy balance (e.g. Wallén, r 948; Hubley, r957). However, it has often been noted that, when the heat sources and sinks are determined by independent methods, there is disagreement between measured and predicted ablation which can be quite significant over short periods (Orvig, I954; Larsson, I960; Ambach, I963[a]; Mayo and Péwé, I963; Andrews, r964; Dibben, I965; Adams, r966; Platt, I966). This disagreement appears, in many cases, to be systematic and quite apart from the not inconsiderable instrumental and observational errors.

* C.M.K. now with U.S. Army Cold Regions Research and Engineering Laboratory, Hanover, New Hampshire 03755 , U.S.A. 


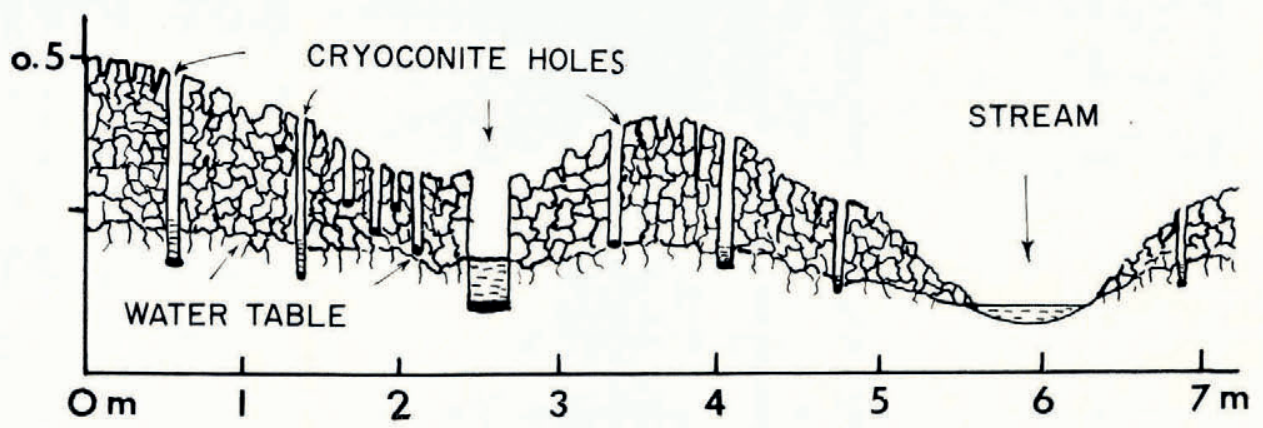

Fig. I. Schematic profile of the weathering crust at the surface of a glacier.

The surface of a glacier experiencing ablation frequently consists of a layer of porous ice with loosely interlocking crystals, varying in thickness from a few to a few tens of centimetres. Such a layer, referred to as a "weathering crust" (Fig. I and 2) is produced by differential absorption of radiant energy along grain boundaries, a process termed internal ablation (interne Ablation) by Ambach (1955). Cryoconite action often intensifies this condition. During the period of formation of the weathering crust more ice is being melted than would be apparent from surface lowering measurements. The opposite is true when, during periods of overcast, windy, and warm weather, the weathering crust is ablated away leaving the surface hard and glazed (Fig. 3), as the gross density of the weathering crust which has been melted away is lower than that of normal glacier ice (sometimes as low as $0.5 \mathrm{~g} \mathrm{~cm}^{-3}$ ). Therefore measurements of surface lowering may give an erroneous impression of high ablation rates.

Furthermore, the progressive changes in the weathering crust are not uniform, as small differences in the physical properties of the ablating surface cause significant local variations in the development of the weathering crust.

In an attempt to locate and quantify the errors inherent in short-term ablation measurements, field work was carried out on the tongue of the White Glacier (lat. $79^{\circ} 26^{\prime} \mathrm{N}$., long. $90^{\circ} 39^{\prime}$ W.), $200 \mathrm{~m}$ above sea-level on Axel Heiberg Island, and on the lower part of the Sverdrup Glacier (lat. $75^{\circ} 43^{\prime}$ N., long. $83^{\circ} 20^{\prime}$ W.), $300 \mathrm{~m}$ above sea-level on Devon Island,

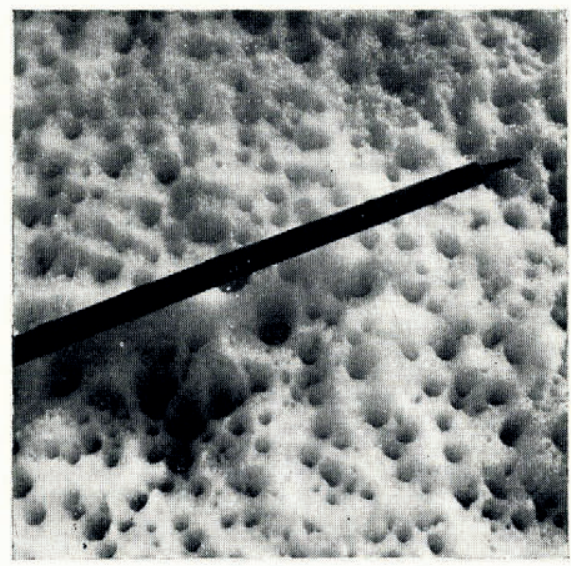

Fig. 2. Glacier surface during a period of prolonged clear weather. Note the numerous cryoconite holes and the lacy texture produced by melting along grain boundaries. 
in the Canadian Arctic Archipelago. Both glaciers are medium-sized, sub-polar valley type, and have an ablation period of about three months (early June to end of August).

Energy-balance studies were conducted and ablation measured using both standard and new techniques. Surface run-off from supraglacial drainage basins was also measured to provide a completely independent value of ablation.

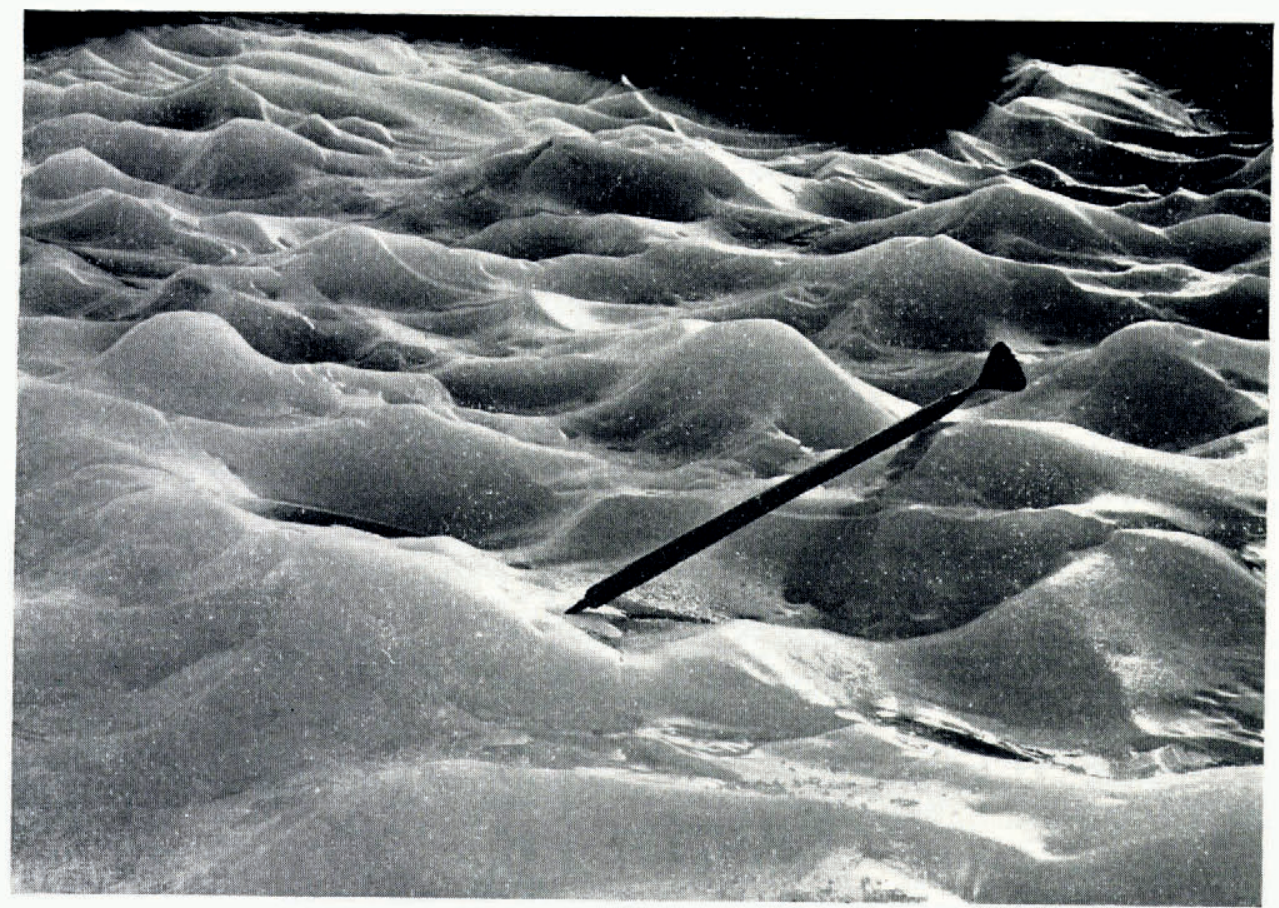

Fig. 3. Glacier surface after a period of overcast, rain and high winds. The surface has become glazed and foliation patterns are exposed.

\section{EnERgy Balance}

The major sources of heat at the freely melting surface of a glacier are incoming solar radiation, incoming long-wave radiation from the atmosphere, latent heat from the freezing of rain, and condensation of vapour and sensible heat transfer from the air. The major causes of heat loss are reflection of radiation, outgoing long-wave radiation, conduction from the surface into the ice or into the air, evaporation, and melt. Such factors as the mechanical energy supplied by running water and cultural disturbances are assumed to be small. The measuring techniques, basic data, and computations used in this study are discussed in detail by Keeler (1964), Havens and others (1965), and Müller (ig68).

The radiation balance was determined from measurements of incoming and reflected solar radiation made with Kipp \& Zonen solarimeters and from the long-wave radiation estimated using the equation of Hoinkes and Untersteiner (1952). This latter was checked against estimates of cloud-base temperatures and appeared to be valid.

The transfer of sensible and latent heats was computed from wind, temperature, and vapour pressure data gathered at various levels in the first $4 \mathrm{~m}$ above the surface. The exchange coefficients were evaluated by assuming a logarithmic wind profile and near neutral stability (such that eddy conductivity is equal to eddy diffusivity and eddy viscosity (Rider 
and Robinson, I95I)). This assumption may be only partially correct; however, it is supported by the form of the wind profiles, the magnitude of computed Richardson numbers, and by the recent study by Grainger and Lister (1966) which shows the logarithmic law to be the most suitable in near neutral conditions, as expected, and also during inversions.

The amount of energy lost by conduction into the ice $\left(Q_{i}\right)$ in the case of both glaciers was

Table I. Components of Short-period Heat Balance Calculations for Melting Ice Surfaces on Axel Heiberg Island (Summers ig61 and 1962) and Devon Island (Summer 1963)

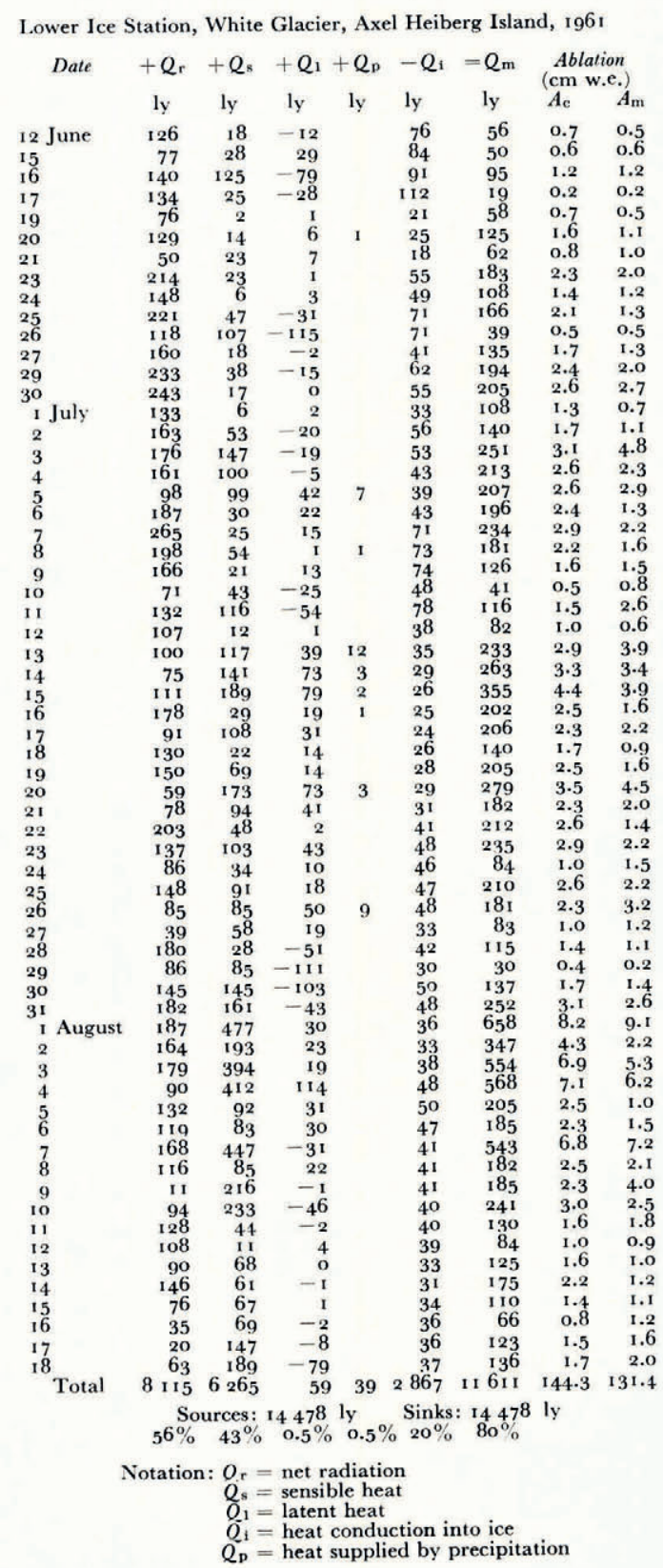

Lower Ice Station, White Glacier, Axel Heiberg Island, 1962

\begin{tabular}{|c|c|c|c|c|c|c|c|c|c|}
\hline $\begin{array}{l}{ }_{16}^{6}-31 \\
\text { Period } \\
\text { no. }\end{array}$ & $\begin{array}{l}\text { July } \\
\text { No. of } \\
\text { hours }\end{array}$ & $\begin{array}{c}+Q_{r} \\
\text { ly }\end{array}$ & $\begin{array}{c}+Q_{8} \\
\text { ly }\end{array}$ & $\begin{array}{c}+Q_{1} \\
\text { ly }\end{array}$ & $\begin{array}{c}+Q_{p} \\
\text { ly }\end{array}$ & $\begin{array}{c}-Q_{1} \\
\text { ly }\end{array}$ & $\begin{array}{c}=Q_{\mathrm{m}} \\
\text { ly }\end{array}$ & $\begin{array}{l}A b l \\
(\mathrm{~cm} \\
A_{\mathrm{c}}\end{array}$ & $\begin{array}{l}\text { ation } \\
\text { w.e. } \\
\qquad A_{\mathrm{m}}\end{array}$ \\
\hline I & 26 & 311 & 194 & 23 & & 44 & 484 & 6.1 & 5.9 \\
\hline $2 \mathrm{~A}$ & 24 & 250 & 61 & 40 & & 38 & 313 & 3.9 & 3.2 \\
\hline $2 B$ & 24 & 275 & 103 & 6 & & $3^{8}$ & $34 \overline{6}$ & $4 \cdot 3$ & 3. I \\
\hline $3 \mathrm{~A}$ & 36 & 327 & 210 & 28 & & 57 & 508 & 6.4 & 9.4 \\
\hline $3 \mathrm{~B}$ & 36 & 503 & 356 & 29 & & 67 & 821 & 10.3 & 10.9 \\
\hline 4 & 36 & 139 & 69 & 75 & & 69 & 214 & 2.7 & 6.8 \\
\hline $5 \mathrm{~A}$ & $4^{8}$ & 383 & 74 & $6 I$ & & 92 & 426 & $5 \cdot 3$ & 3.2 \\
\hline $5 B$ & 36 & 312 & 28 & 6 & & $4^{6}$ & 300 & 3.8 & 3.4 \\
\hline 6 & 48 & 410 & 44 & 9 & & 55 & 408 & 5.1 & 3.4 \\
\hline 7 & 24 & 114 & i i & 8 & & 28 & 105 & 1.3 & 3.2 \\
\hline 8 & 24 & 82 & 153 & 5 & & 28 & 212 & 2.7 & 6.2 \\
\hline Total & 362 & 3106 & 1303 & 290 & & 562 & 4137 & 51.9 & 58.7 \\
\hline & & $66^{\circ}$ & rces & 69 & & $\begin{array}{l}\text { Sin } \\
12\end{array}$ & $\begin{array}{r}469 \\
88\end{array}$ & & \\
\hline
\end{tabular}

Sverdrup Glacier, Devon Island, 1963

\begin{tabular}{|c|c|c|c|c|c|c|c|c|}
\hline \multirow[t]{2}{*}{ Date } & $+Q_{r}$ & $+Q_{s}$ & $+Q_{1}$ & $+Q_{p}$ & $-Q_{i}$ & $=Q_{m}$ & \multicolumn{2}{|c|}{$\begin{array}{l}\text { Ablation } \\
\text { (cm w.e.) }\end{array}$} \\
\hline & ly & ly & ly & ly & ly & ly & $A_{\mathrm{c}}$ & $A_{\mathrm{m}}$ \\
\hline July & 74 & 7 & 2 & & 27 & 56 & 0.7 & 0.5 \\
\hline & $9^{1}$ & II & 6 & & 23 & 85 & I, I & 1.5 \\
\hline & $4^{2}$ & 17 & 0 & & 23 & 36 & 0.5 & 0.4 \\
\hline & 71 & $3^{8}$ & 18 & & 30 & 97 & 1.2 & 1.0 \\
\hline & 111 & 57 & 24 & & 27 & 165 & 2.1 & I.O \\
\hline & I 29 & 39 & 14 & & 37 & 145 & 1. 8 & 0.7 \\
\hline & 111 & 43 & 23 & & 37 & 140 & 1.8 & 1.0 \\
\hline & 165 & 76 & 29 & & 37 & 233 & 2.9 & I. 4 \\
\hline & 140 & 87 & 42 & & 37 & 232 & 2.9 & 1.0 \\
\hline & 148 & 82 & I9 & & 42 & 207 & 2.3 & 0.9 \\
\hline & 128 & 36 & 9 & & 28 & 145 & 1.6 & 0.8 \\
\hline & 140 & 8 & 0 & & I8 & 130 & І. 6 & 0.5 \\
\hline & 130 & 21 & 10 & & 18 & I 43 & 1.8 & 0.5 \\
\hline & I 18 & 7 & 0 & & 14 & 111 & 1.4 & 0.9 \\
\hline & 141 & 24 & 12 & & 19 & I $5^{8}$ & 2.0 & 1.0 \\
\hline & I09 & 51 & 23 & & 19 & 164 & 2.0 & 1.8 \\
\hline & 129 & 103 & 31 & & 19 & 244 & 3.1 & 2.4 \\
\hline 0 & 121 & 112 & $3^{8}$ & & 21 & 250 & 3.1 & 2.5 \\
\hline 7 & I 36 & 115 & $4^{8}$ & 7 & 28 & 278 & 3.6 & 4.4 \\
\hline 8 & 125 & 86 & 50 & & 20 & 241 & 3.0 & 5.5 \\
\hline 9 & 33 & 47 & 19 & 4 & 20 & 83 & 1.0 & 4.3 \\
\hline 30 & 123 & $3^{8}$ & 23 & 3 & 20 & 167 & 2.1 & 3.0 \\
\hline $3 \mathrm{I}$ & 75 & 47 & 53 & 8 & 20 & I63 & 2.0 & 4.2 \\
\hline I August & 83 & 225 & 146 & & 20 & 434 & 5.4 & 6.1 \\
\hline 2 & 118 & $16 \mathrm{I}$ & 69 & & 20 & 328 & $4 \cdot I$ & 5.4 \\
\hline 3 & 123 & 59 & 26 & & 20 & 188 & 2.4 & 1.5 \\
\hline 4 & I 54 & 36 & 15 & & 20 & 185 & $2 \cdot 3$ & 2.0 \\
\hline 5 & $\begin{array}{l}1 \\
19\end{array}$ & 17 & 9 & & 16 & 129 & 1.4 & 1.3 \\
\hline 6 & 12 & 24 & 10 & 2 & 20 & 28 & 0.4 & I. I \\
\hline $\begin{array}{l}7 \\
8\end{array}$ & 123 & 40 & 24 & & 20 & 167 & 2.1 & 3.2 \\
\hline 8 & 69 & 49 & I & & 13 & 106 & 1.3 & 1.7 \\
\hline 9 & $4^{2}$ & 191 & 112 & & 16 & 329 & $4 \cdot 1$ & 4.8 \\
\hline & 55 & 165 & 64 & & 16 & 268 & 3.4 & $4 \cdot 7$ \\
\hline Total & $34^{88}$ & 2119 & 969 & 24 & 765 & 5835 & 72.5 & 73.0 \\
\hline & & ources & 6600 & ly & Sinks & $=\begin{array}{r}6600 \\
88^{\circ}\end{array}$ & & \\
\hline & $\begin{aligned} Q_{\mathrm{m}} & = \\
A_{\mathrm{c}} & = \\
A_{\mathrm{m}} & = \\
\mathrm{ly}_{\mathrm{y}} & =\end{aligned}$ & ea & me & & . & 868 & & \\
\hline
\end{tabular}


considerable. Series of thermistors and thermocouples were inserted to a depth of $\mathrm{I} 5 \mathrm{~m}$, with a spacing of $25 \mathrm{~cm}$ in the upper third of the profile. These were read periodically and heat conduction computed by integrating between successive depth-temperature curves.

Heat supplied by precipitation was minor. The temperature of the rain was assumed to be the same as the $150-\mathrm{cm}$ air temperature.

Table I summarizes the short-period (usually daily) heat-balance terms obtained on Axel Heiberg Island in 1961 and 1962 and on Devon Island in 1963 . The values for calculated melt were found by dividing the available heat by the heat of fusion of ice. These figures are subject to considerable error arising from such factors as type of instrument, low solar angle in the case of radiation, sampling time, deviation from a logarithmic wind structure and operator error. A conservative estimate indicates that there may be as much as a 30 per cent error for any daily value of the heat sources. Therefore some caution should be exercised in using these figures.

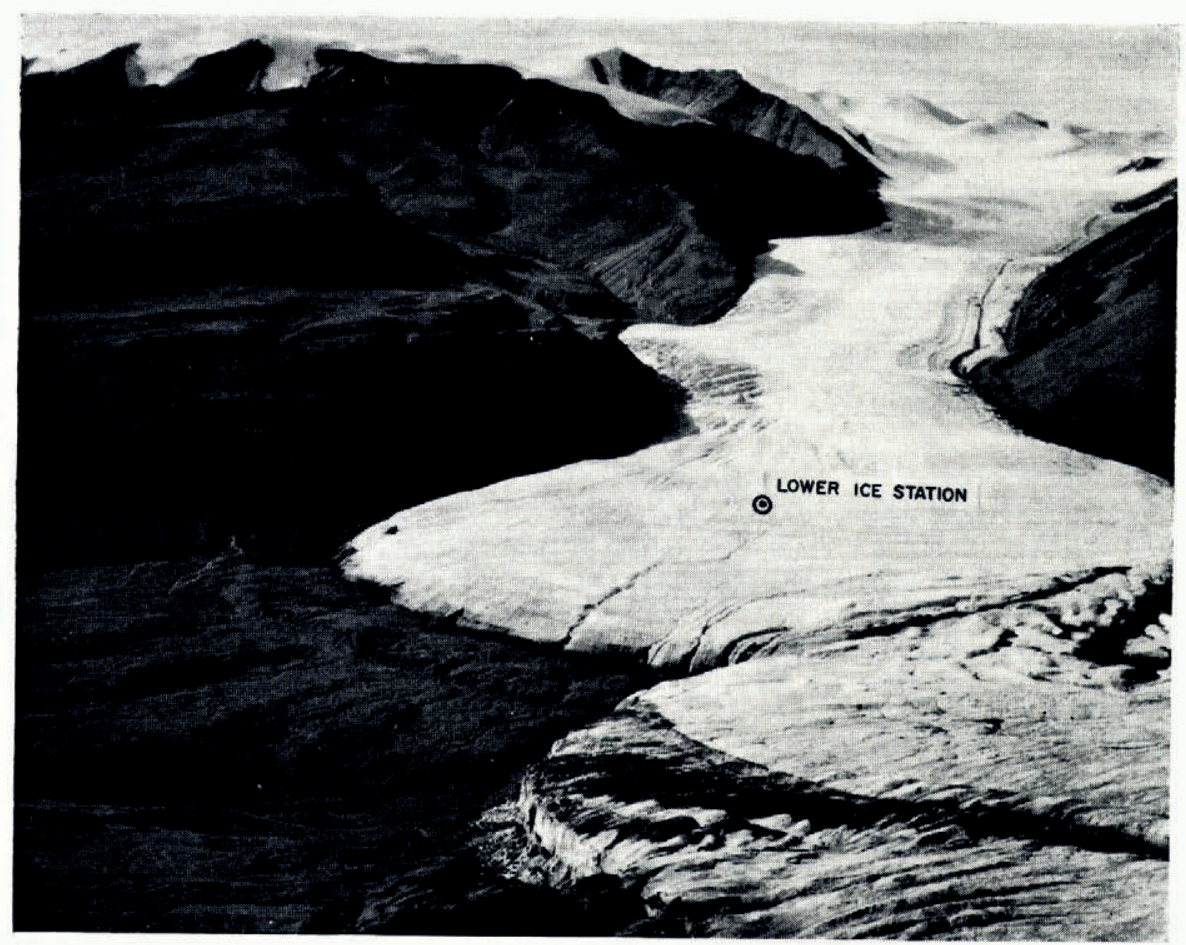

Fig. 4. The site of the ablation measurements on the White Glacier, Axel Heiberg Island: the surrounding of the Lower Ice Station.

\section{Measurement of Ablation}

Ablation quantities can be obtained from various measurements such as: surface lowering, run-off from supraglacial basins, mass change, and ice discharge past the equilibrium line of a glacier in a balanced state. All except the latter were tried and a discussion of the precision and accuracy of each follows.

\section{Surface lowering}

Measuring the lowering of the surface level relative to a fixed point is the common method of assessing mass wastage. The height difference is converted to a mass figure by multiplying by the density which is assumed to remain constant with respect to time and space. 
On the White Glacier, Axel Heiberg Island, surface lowering was measured in the centre of the tongue about half a kilometre from the edge by various methods (Fig. 4 and 5). Five bamboo poles were drilled into the ice ("Lower Ice Diamond") $20 \mathrm{~m}$ from the meteorological station. In a shallow drainage basin, located $60 \mathrm{~m}$ up-glacier from the station, I $\mathrm{I}$ aluminum poles were inserted and two star ablatometers were installed. In addition, four stakes of the longitudinal profile (L), spaced at $100 \mathrm{~m}$ intervals, were included in this ablation survey.

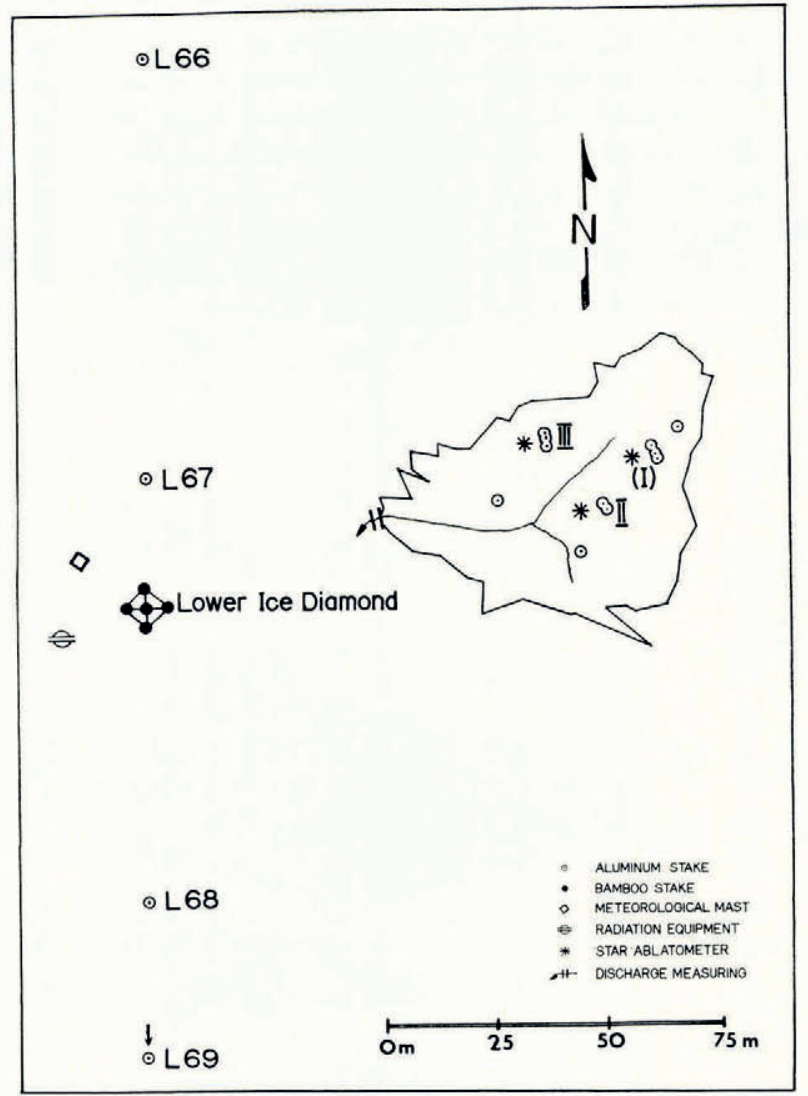

Fig. 5. The locations of various ablation and micro-meteorological measurements in the test area at the Lower Ice Station.

\section{Stake measurement}

Melt hollows caused by the heat absorption of the stake and the complex micro-relief of the ice surface made the usual technique of measuring surface lowering on stakes difficult and often inaccurate. Some consistency and objectivity was achieved by measuring to the underside of a $50-\mathrm{cm}$ straight edge laid first parallel then perpendicular to the direction of glacier flow. This technique is referred to as the straight-edge method. The mean of the two readings, however, does not necessarily represent the true lowering of the surface surrounding the stake as the rate of lowering of the peaks of the micro-relief, the points in contact with the straight edge, may differ from that of the total surface. The measuring error for this method at any one stake was found to average $\pm 0.5 \mathrm{~cm}$ for the many different surface conditions in the test area diring one summer. In addition, the often large standard deviations associated with the mean of several stake readings indicated uncertainties in the daily values which were frequently of the same order of magnitude as the values themselves. 


\section{The star ablatometer}

In an attempt to obtain a more accurate surface lowering value for an area of $\mathrm{I} m$ radius around a stake, a portable ablatometer was designed (Fig. 6). A six-arm metal star is mounted on the stake. Thirty-six points are measured by the lowering of a thin rod through the six sleeved holes in each arm. The rod contacts a variety of surface points including both peaks and depressions of the micro-relief and penetrates the larger cryoconite holes and some of the spaces between loose crystals. Thus the star ablatometer incorporates some information on the changes within the weathering crust in the surface lowering value and therefore yields a more accurate measure of ablation than the straight-edge method. The equipment is removed between measurements, thus obviating the interference that additional stakes would cause. From repeated measurements during a time of no ablation the instrumental error was found to be approximately $\pm 0.3 \mathrm{~cm}$. With the large number of observations available from the star ablatometer the probability that the sample mean is representative of the true mean is

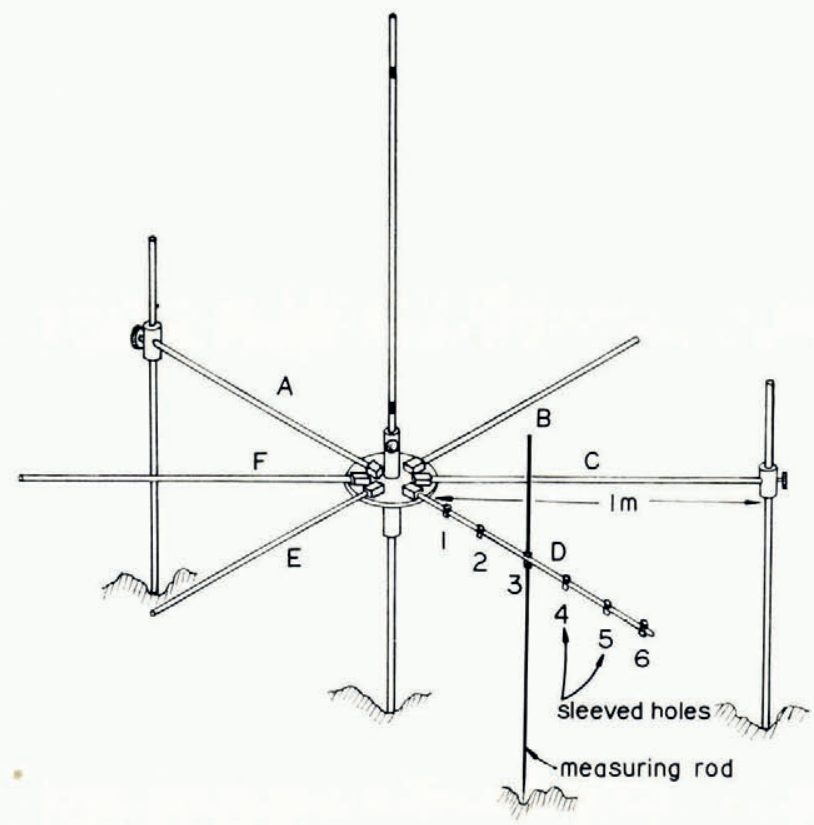

Fig. 6. The star ablatometer.

99 per cent, accepting the above stated accuracy. The probability of obtaining true daily mean values with an accuracy of $\pm 0.5 \mathrm{~cm}$ from the 5 stakes of the "Lower Ice Diamond" using the straight-edge method was at the most go per cent. A Buchow, Höhne and Raeuber error-graph, as reproduced by Untersteiner (I96I), was used to establish these probabilities. It must be stressed that even these mean values are, because of the changes in the weathering crust from one reading to the next, not necessarily accurate measures of true ablation.

\section{The ablatograph}

Attempts to obtain continuous records of the surface lowering with ablatographs equipped with different types of floats produced very doubtful values. It became obvious that, particularly on days of high insolation, due to the considerable changes in the weathering crust, ablatographs, however well designed, are unable to measure the very thing for which they are made, i.e. the short-term variations in the ablation rate. 
Comparison of the surface lowering data

Table II gives the short-period surface lowering values and their 68 per cent confidence limits $\sigma / n^{\frac{1}{2}}$, as obtained by the various measuring techniques used at the different locations of the test area on Axel Heiberg Island. All data are converted to centimetres of water to permit direct comparison with the run-off data and the melt calculated from the meteorological elements. The differences between the daily values for the various sites are often considerable -in some cases more than 200 per cent. The totals for the entire observation period differ much less, only up to 20 per cent. The standard errors of the sample means of daily surface lowering for the "Lower Ice Diamond" average 47 per cent, while the corresponding error of the sample mean for the season amounts to 3 per cent. Likewise the errors for the shortperiod values obtained from the two star ablatometers average I 7 per cent (II) and I 3 per cent (III), while the standard errors for the sample means for the total surface lowering at the two sites are less than 2 per cent.

The fact that the differences between the values at the various sites are greater for short periods than for long ones substantiates the idea that the errors in short-period measurements are largely compensatory in time due to the fluctuating nature of the weathering crust. Discrepancies in both daily and longer-term values between the different sites clearly indicate an

Table II. Comparison of Ablation Values obtained by Different Methods and at Different Locations near Lower Ice Station, A.H.I., Summer 1961. Values are given in cm of Water

\begin{tabular}{|c|c|c|c|c|c|c|c|c|c|c|}
\hline \multirow{2}{*}{$\begin{array}{l}\text { Date } \\
196 I\end{array}$} & \multirow{2}{*}{$\begin{array}{c}\text { Straight-edge } \\
5 \text { stakes in diamond } \\
\text { near met. mast } \\
\\
\begin{array}{c}\text { mean }(\bar{x})+\text { error } \\
\sigma / n^{\overline{1}}\end{array}\end{array}$} & \multirow{2}{*}{$\begin{array}{l}\text { Ablato- } \\
\text { graph } \\
\text { near } \\
\text { met. } \\
\text { mast }\end{array}$} & \multicolumn{2}{|c|}{$\begin{array}{c}\text { Star ablatometers } \\
36 \text { readings } \\
\text { in basin }\end{array}$} & $\begin{array}{l}\text { Straight-edge } \\
\text { I I random stakes } \\
\text { in basin }\end{array}$ & \multirow[b]{2}{*}{$\begin{array}{l}\text { Run-off } \\
\text { from } \\
\text { basin }\end{array}$} & \multicolumn{4}{|c|}{$\begin{array}{c}\text { Straight-edge } \\
4 \text { individual stakes } \\
\text { in L-profile }\end{array}$} \\
\hline & & & $\begin{array}{c}\text { No. II } \\
\bar{x} \pm \text { error }\end{array}$ & $\begin{array}{l}\text { No. III } \\
\bar{x} \pm \text { error }\end{array}$ & $\bar{x} \pm$ error & & L66 & L67 & L68 & L69 \\
\hline \multicolumn{11}{|l|}{ July } \\
\hline $2 \mathrm{I}$ & $2.0 \pm 0.3$ & & I. $5 \pm 0.2$ & - & $1.4 \pm 0.5^{*}$ & & & & & \\
\hline 22 & $1.4 \pm 0.2$ & & $2.3 \pm 0.5$ & $\bar{c}$ & $1.4 \pm 0.5^{*}$ & & & & & \\
\hline $\begin{array}{l}23 \\
24\end{array}$ & $\begin{array}{l}2.2 \pm 0.2 \\
1.5 \pm 0.3\end{array}$ & 2.5 & $3.8 \pm 0.4$ & $2.6 \pm 0.1$ & $2.3 \pm 0.2$ & $3 \cdot 3$ & $9 \cdot 0$ & 7.2 & 7.2 & 8.8 \\
\hline 25 & $2.2 \pm 0.3$ & & & & & & & & & \\
\hline $\begin{array}{l}26 \\
27\end{array}$ & $\begin{array}{l}3.2 \pm 0.2 \\
1.2 \pm 0.1\end{array}$ & & $8.7 \pm 0.8$ & $10.0 \pm 0.5$ & $8.9 \pm 0.9$ & & & & & \\
\hline 28 & I. $\mathrm{I} \pm 0.6$ & & & & & & 10.4 & 8.8 & I I.O & $9 \cdot 7$ \\
\hline 29 & $0.2 \pm 0.1$ & & & & & & & & & \\
\hline $\begin{array}{l}30 \\
31\end{array}$ & $1.4 \pm 0.2$ & 2.0 & $1.9 \pm 0.5$ & $2.1 \pm 0.4$ & $\mathrm{I} . \mathrm{I} \pm 0 . \mathrm{I}$ & 2.7 & " & & & \\
\hline $\begin{array}{c}3^{I} \\
\text { Aug }\end{array}$ & $2.6 \pm 0.5$ & 一 & $8.1 \pm 0.7$ & $4.5 \pm 0.7$ & $2.5 \pm 0.2$ & $4 \cdot I$ & & & & \\
\hline \multicolumn{11}{|l|}{ Aug. } \\
\hline $\begin{array}{l}\text { I } \\
2\end{array}$ & $9.1 \pm 0.6$ & & & & & & & & & \\
\hline $\begin{array}{l}2 \\
3\end{array}$ & $2.2 \pm 0.4$ & & & & & & & & 26.8 & \\
\hline $\begin{array}{l}3 \\
4\end{array}$ & $\begin{array}{l}5.3 \pm 0.3 \\
6.2+0.3\end{array}$ & & & & & & 27.0 & 23.0 & 20.0 & $24 \cdot 1$ \\
\hline $\begin{array}{l}4 \\
5\end{array}$ & $\begin{array}{l}0.2 \pm 0.3 \\
1.0 \pm 0.2\end{array}$ & & $29.9 \pm 1.1$ & $30.2 \pm 0.9$ & $29 \cdot 3 \pm 4 \cdot 4$ & & & & & \\
\hline 6 & $1.5 \pm 0.3$ & & & & & & & & & \\
\hline $\begin{array}{l}7 \\
8\end{array}$ & $\begin{array}{l}7.2 \pm 0.4 \\
2.1 \pm 0.5\end{array}$ & & & & & & 15.8 & $\mathrm{I} 6.3$ & 20.9 & I 8.6 \\
\hline 9 & $4.0 \pm 0.2$ & 2.8 & $3.0 \pm 0.5$ & $4.2 \pm 0.3$ & $4.0 \pm 0.3$ & I. 2 & & 20.0 & 20.9 & \\
\hline IO & $2.5 \pm 0.3$ & 1.7 & $3.1 \pm 0.6$ & $2.3 \pm 0.3$ & $2.5 \pm 0.4$ & I. 4 & & & & \\
\hline I I & 1. $8 \pm 0.3$ & 一 & & $\mathrm{I} .9 \pm 0.2$ & г. $8 \pm 0.4$ & 2.8 & & & & \\
\hline I 2 & $0.9 \pm 0.2$ & & $0.9 \pm 0.6$ & $1.0 \pm 0.2$ & $0.7 \pm 0.1$ & & & & & \\
\hline I3 & $1.0 \pm 0.2$ & - & $\mathrm{I}, \mathrm{I} \pm \mathrm{O} . \mathrm{I}$ & $1.3 \pm 0.2$ & I. $4 \pm 0.2$ & 0.8 & 7.2 & $6 . \mathrm{I}$ & $7 \cdot 4$ & $9 \cdot 5$ \\
\hline 14 & $1.2 \pm 0.3$ & - & $\mathrm{I} . \mathrm{I} \pm 0 . \mathrm{I}$ & $1.7 \pm 0.2$ & $1.2 \pm 0.2$ & 0.7 & & & & \\
\hline${ }^{1} 5$ & $1.1 \pm 0.2$ & 1.5 & I. $6 \pm 0.1$ & $1.5 \pm 0.2$ & $1.2 \pm 0.3$ & 0.8 & & & & \\
\hline 16 & $1.2 \pm 0.3$ & & $1.2 \pm 0.5$ & $1.3 \pm 0.3$ & $0.7 \pm 0.2$ & & & & & \\
\hline I7 & $1.6 \pm 0.3$ & - & $1.6 \pm 0.2$ & $1.6 \pm 0.3$ & $2.1 \pm 0.1$ & I. 4 & 3.6 & $3 \cdot 4$ & $4 \cdot 5$ & $4 \cdot 1$ \\
\hline $\begin{array}{c}18 \\
\text { Total }\end{array}$ & $2.0 \pm 0.6$ & - & $\mathrm{I} . \mathrm{I} \pm 0 . \mathrm{I}$ & I. $8 \pm 0.3$ & $1.4 \pm 0.4$ & 0.8 & & & 77.8 & 74.8 \\
\hline Total & $70.9 \pm 2.1$ & & $65.9 \pm 1.1$ & $68.0 \pm 1.2$ & $63.9 \pm 1.4$ & & 73.0 & $05 \cdot 4$ & 77.0 & 74.0 \\
\hline
\end{tabular}

* Incomplete data. 
additional problem - that unexpectedly large spatial variations in the amounts of surface lowering, and therefore also in ablation, occur over short distances on seemingly uniform surfaces. These must be attributed to changes, which would be hard to observe, in albedo, in micro-relief (causing differences in sensible and latent heat exchanges), in the physical properties of that surface layer which undergoes weathering, and in the melt-water drainage.

Based on this latter observation, the 1962 surface lowering on the White Glacier was measured in close proximity to the site of the energy-balance study. A simple frame ablatometer, similar to the star ablatometer, constructed from "Dexion" slotted angle aluminum, permitted 36 individual readings evenly distributed over an area of $1 \mathrm{~m}^{2}$. Thirteen shortperiod mean surface lowering values ( 24 to $48 \mathrm{~h}$ ) obtained with this equipment between I 6 and $3 \mathrm{I}$ July had standard errors between 4 per cent and 18 per cent.

In 1963 further surface lowering measurements were carried out approximately in the centre of the ablation area of the Sverdrup Glacier, Devon Island. Eleven bamboo stakes were drilled into the ice in the vicinity of the meteorological mast and along the perimeter of a supraglacial drainage basin. Despite the precaution of using the straight-edge method the standard deviation of the daily means gained from the stakes was frequently extremely high, again suggesting that ablation varies considerably over short distances.

In order to increase the accuracy of the measurements, near the meteorological mast a device was constructed similar to the frame ablatometer used on Axel Heiberg Island. It consisted of three stakes arranged in a triangle, with legs of $\mathrm{I} \mathrm{m}$, between which was stretched a marked wire. Measurements were made along the wire at $10 \mathrm{~cm}$ intervals with a probe. This allowed 30 individual readings to be made in an area of $0.5 \mathrm{~m}^{2}$. This number of readings allows 95 per cent confidence that the sample mean does not differ from the population mean by more than $\pm 0.25 \mathrm{~cm}$ of water. A second such ablatometer was set up in the upper part of the catchment basin to provide a check on the representativeness of the mast-site observations. The seasonal values for the two ablatometers are $58.1 \mathrm{~cm}$ and $66.1 \mathrm{~cm}$ respectively and 78.7 $\mathrm{cm}$ for the stakes. The measuring error for these ablatometers was determined to be $\pm 0.3 \mathrm{~cm}$. The difference between the two ablatometers is significant at the I per cent level. This was expected as the difference in surface albedo between the two areas was io per cent, the upper site having the lower albedo. The high value given by the stakes may partly be due to accelerated melt in their immediate vicinity.

\section{Direct Measurement of Mass Loss}

If one accepts that one of the major sources of error in short-term ablation measurements on ice is the variation in surface density then an assessment of mass, rather than surface-level, change would be more valid.

Ambach (1963[a], [b]) suggested calculating the change in density (or porosity) from measurements of the radiation extinction within the upper ice layers. He and his co-workers developed several small size thermo- and photo-electrical receivers to measure the radiation intensity, balance and direction. This approach produced some interesting results, as for example those reported from Greenland (Ambach, 1963[a]). But still very large numbers of measurements within the area and time period are necessary because of the great variations in the weathering crust over short distances.

Hubley (1954) discussed the problems for the case of snow from a theoretical point of view and presented an equation for ablation which includes both changes in surface level and density as functions of time.

$$
\frac{\mathrm{d} M}{\mathrm{~d} t}=\rho_{h} \frac{\mathrm{d} h}{\mathrm{~d} t}+\int_{0}^{h} \frac{\mathrm{d} \rho}{\mathrm{d} t} \mathrm{~d} z
$$


where $M$ is the total mass of snow in a column of unit area and height $h$, having a density $\rho$, which is a function of depth $z$. LaChapelle (1959) developed a practical field method for snow. He showed that, when density is a function of time, mass loss can be found by integration between two successive depth-density curves. The idealized situation is depicted in Figure 7. The change in mass $\Delta M$ between times $t_{0}$ and $t_{1}$, is given by

$$
\Delta M=\int_{0}^{h_{0}} \rho\left(h, t_{0}\right) \mathrm{d} h-\int_{0}^{h_{0}} \rho\left(h, t_{\mathrm{r}}\right) \mathrm{d} h .
$$

The difficulty with this technique is in making a sufficient number of density measurements to draw depth-density curves. This is possible although tedious for snow surfaces but next to impossible for ice.

An alternate method is to core into the glacier from an established reference horizon. The ablation is equal to the difference between the mass of ice in the core at two successive readings. This method is extremely simple requiring only a coring device. While having a rather small sampling area, the standard SIPRE 3 -inch $(7.6 \mathrm{~cm})$ diameter coring auger is readily available. In 1963 , this sampling technique was extensively used on Devon Island after some exploratory

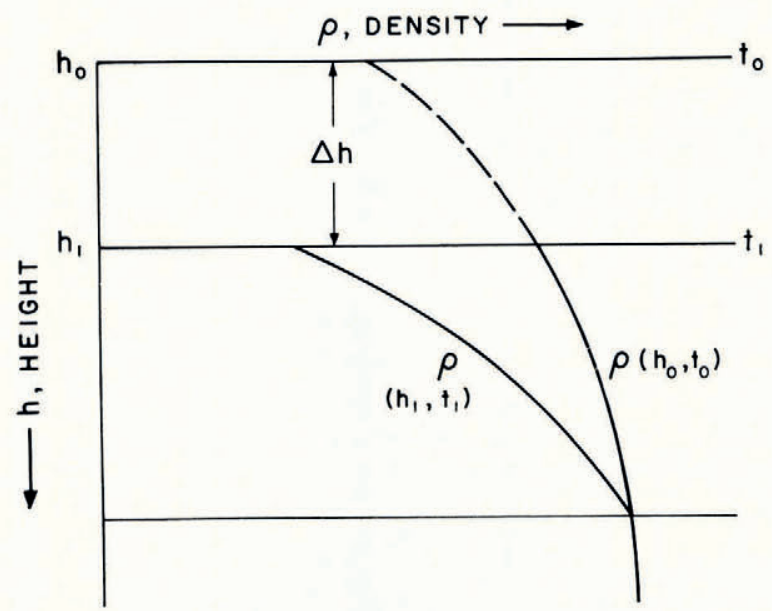

Fig. 7. Two successive ideal depth-density curves on a melting glacier (after LaChapelle, 1959).

studies with more sophisticated equipment, as for example a specially designed hot-point corer of $26 \mathrm{~cm}$ diameter which failed in application. Although there were usually only two density values measured per profile, the data permitted plotting simple depth-density curves as shown in Figure 8. Figure 8a illustrates a case in which there was sub-surface melt amounting to more than one half of the actual mass loss, and Figure $8 \mathrm{~b}$ presents a situation in which there was a low density surface layer which vanished without additional sub-surface melt. Daily mass-loss measurements accrued for the period i 5 July to 6 August ig63. The primary source of error in direct mass-change measurements with the coring technique was the fact that each area could only be sampled once. The lateral variation in the depth of the weathering crust is such that an erroneous impression of mass loss or gain may result. The weathering crust tends to be deeper over ridges than in depressions where radiation has less access and where running water erodes much of it. Thus it becomes necessary to adopt the subjective procedure of sampling in selected topographically similar locations. It is estimated that, despite this difficulty, the errors of direct mass-loss measurements are less than those of any of the other techniques discussed in this paper. Large numbers of samples and the development of a larger diameter corer would allow a more representative assessment of the mass losses. 

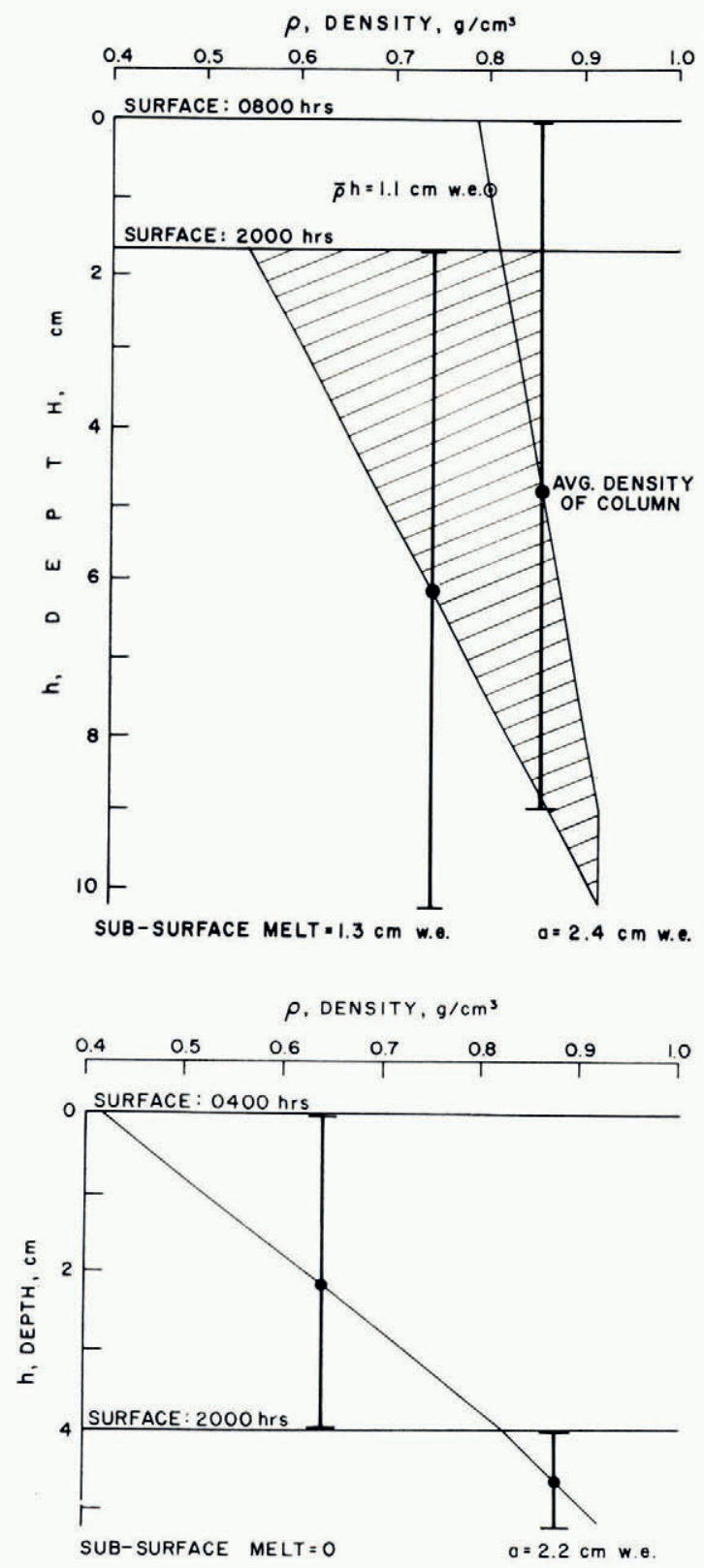

Fig. 8. Examples of field determinations of mass loss. Figure 8 a (above) shows the case for clear sky conditions with sub-surface melt $\left(16 \mathrm{Full}_{1} \mathrm{19}_{63}\right)$ and Figure 86 (below), the case for rain and wind with surface scour (29. Fuly 1963$)$.

\section{Surface Run-off Measurements}

Assuming that the ice is impermeable and that evaporation is negligible then surface run-off should be equal to the amount of ice melted and within a small drainage basin there should be little time lag between the melt and the run-off. On both the White and the Sverdrup Glaciers small drainage basins $\left(3360 \mathrm{~m}^{2}\right.$ and $\left.4860 \mathrm{~m}^{2}\right)$ were delineated for selected periods of 
measurements of discharge using the sodium dichromate method (Dumas, 1952-53). This technique is described fully by Adams ( 1961 , I966) and Keeler (1964). As the colorimetric analysis of the collected samples was quite time-consuming, it was only possible to sample every six hours on Axel Heiberg Island and every four hours on Devon Island. It was found that spot discharge quantities with the dilution method are accurate to \pm 5 per cent even under field conditions, however the necessity for interpolation to derive the daily hydrograph decreases the accuracy for the daily quantities. Time lags between the melt and discharge peaks of from three to six hours, depending on the permeability of the weathering crust must be taken in consideration when calculating daily melt. Consequently the ablation values gained by this method do not constitute a reliable standard against which to judge values obtained by other methods.

\section{Comparison of Various Measures of Ablation}

Values of ablation calculated from the energy balance $\left(A_{\mathrm{c}}\right)$ were compared with those measured from surface lowering $\left(A_{\mathrm{m}}\right)$ and were found to be in closer agreement over long than short periods. To assess the hypothesis that the difference between observed and calculated short-term ablation stands in a causal relationship to changes in the micro-climatic conditions prevailing at the surface, the ratio of measured ablation to ablation calculated from the energy balance has been plotted against the per-cent contribution of radiation to the total energy sources (Fig. 9). While the scatter is great there appears to be a trend indicative of under-estimates of ablation during periods of high insolation and the converse during periods of low insolation. An alternative plotting of $A_{\mathrm{m}} / A_{\mathrm{c}}$ versus the sunshine duration (expressed in per cent of possible) was tried; however, a similarly low correlation was obtained. It is clear that no single climatic parameter can be used to establish the relationship between ablation and climate.

Ablation quantities obtained by various methods of measurement are compared with the melt calculated from the energy balance in Table III. As mentioned before it can be seen that over long periods the differences are negligible while for short periods they are considerable. In all cases direct measurements of mass change seem to correlate better with expected melt than do measurements of surface lowering. It is not known why the discharge figure for 2 August is so low in comparison with the other values of ablation.

Table III. Comparison of Values of Ablation (in cm of Water)

Obtained by Various Methods, Devon Island, Summer rg63

\begin{tabular}{|c|c|c|c|c|}
\hline Date & Energy balance & $\begin{array}{c}\text { Method } \\
\text { Surface lowering }\end{array}$ & Mass change & Discharge \\
\hline I5 July & 1.7 & I.O & 2.0 & \\
\hline I6 & 2.9 & I. 4 & 3.1 & \\
\hline 20 & I. 6 & 0.5 & 1.5 & 1. 8 \\
\hline $2 \mathrm{I}$ & 1. 8 & 0.5 & 2.2 & 1.2 \\
\hline 23 & 2.0 & 1.0 & 2.4 & \\
\hline 25 & 3.0 & 2.4 & 2.7 & \\
\hline 26 & 3.I & 2.5 & 3.0 & \\
\hline $\begin{array}{l}27 \\
28\end{array}$ & 3.6 & $4 \cdot 4$ & $\begin{array}{l}3 \cdot 7 \\
2.6\end{array}$ & \\
\hline 28 & 3.0 & 5.5 & 2.6 & \\
\hline 29 & 1.0 & $4 \cdot 3$ & 2.3 & 1.9 \\
\hline $3^{\circ}$ & 2. I & 3.0 & 1.7 & г. 6 \\
\hline I August & 5.4 & 6.1 & 6.0 & \\
\hline 2 & 4.1 & $5 \cdot 4$ & 4.8 & I. 9 \\
\hline 3 & 2.4 & I. 5 & I. 0 & I. 3 \\
\hline 4 & 2.3 & 2.0 & 2.0 & \\
\hline 5 & 1. 4 & I. 3 & I. 5 & \\
\hline 6 & 0.3 & I.I & 0.9 & \\
\hline Total & 41.7 & 43.9 & 43.4 & \\
\hline
\end{tabular}




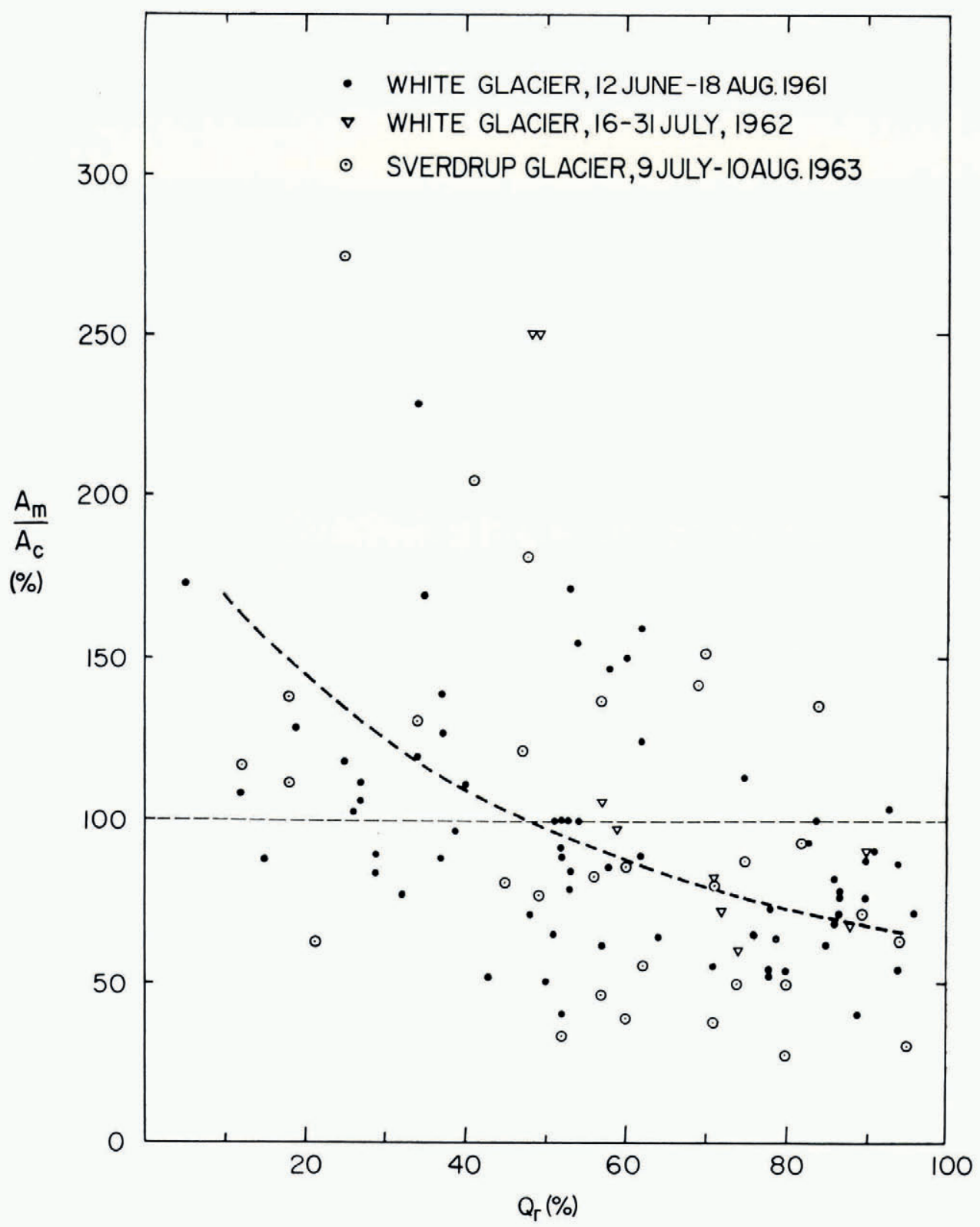

Fig. 9. Plot of the ratio of ablation measured from stakes to ablation calculated from the energy balance versus the per cent contribution of radiation to the energy sources.

\section{Summary and Conclusions}

The large differences in the short-period ablation values obtained from various methods of measurement and from energy balance calculation (Tables I and II) reveal a systematic error which is related to mass losses in the weathering crust.

An investigation of the various errors involved (instrumental, sampling and the above mentioned systematic error) led to the following conclusions: (I) The usual techniques of 
measuring ablation with stakes, ablatometers and ablatographs are, in many cases, inadequate for assessing short-term values. (2) The discharge method, in spite of highly accurate individual readings, does not provide a satisfactory measure for short-term ablation because of the varying time-lag between melt and run-off, and the laborious field-work entailed. (3) The direct measurement of mass loss (surface lowering plus melt in the weathering crust) is feasible with relatively simple equipment and yields data which are in fairly close agreement with the calculated short-term ablation values (Table III). It appears that this method is more satisfactory than any other both in terms of accuracy and expediency in the field. The development of more sophisticated equipment could improve the results obtained.

Spatial variations in the weathering crust occurring even over short distances were found to be of considerable significance in the short-term ablation measurements. Consequently any short-period micro-climatic observations must be carried out in the closest proximity possible to the ablation measurements with which they are to be correlated.

Fortunately, over longer time spans the main errors inherent in short-term ablation measurements are not accumulative but clearly cancel out, and are therefore of little consequence in mass-balance computations.

\section{Acknowledgements}

The main support for this investigation was provided by the National Research Council of Canada. The Arctic Institute of North America, through its Devon Island Project, supported the field work of C. M. Keeler on the Sverdrup Glacier. The assistance in the field and in the office by many is gratefully acknowledged. Particular thanks go to W. Peter Adams, who collected most of the ig6i ablation data.

MS. received 20 May 1968

\section{REFERENCES}

Adams, W. P. 1961. Ablation and run-off studies. (In Müller, F., and others. Jacobsen-McGill Arctic Research Expedition to Axel Heiberg Island, Queen Elizabeth Islands. Preliminary report of $1959-1960$, by F. Müller and members of the expedition. Montreal, McGill University, p. 63-79.)

Adams, W. P. 1966. Glaciology, No. I. Ablation and run-off on the White Glacier, Axel Heiberg Island, Canadian Arctic Archipelago. Axel Heiberg Island Research Reports, McGill University, Montreal. Jacobsen-McGill Arctic Research Expedition $1959-1962$.

Ambach, W. 1955. Über die Strahlungsdurchlässigkeit des Gletschereises. Sitzungsberichte der Österreichischen Akademie der Wissenschaften. Math.-naturwiss. Klasse, Abt. 2, Bd. I64, Ht. Io, p. 483-94.

Ambach, W. 1963 [a]. Untersuchungen zum Energieumsatz in der Ablationszone des grönländischen Inlandeises (Camp IV-EGIG, $69^{\circ} 40^{\prime}$ o5" N, $49^{\circ} 37^{\prime} 59^{\prime \prime} \mathrm{W}$ ). Meddelelser om Gronland, Bd. I 74, Nr. 4.

Ambach, W. I963[b]. Zur Bedeutung der Strahlungsextinktion im Gletschereis für Energieumsatzstudien. Acta Physica Austriaca, Bd. 16, Ht. 3-4, p. $382-84$.

Andrews, R. H. 1964. Meteorology, No. I. Meteorology and heat balance of the ablation area, White Glacier, Canadian Arctic Archipelago-summer 1960. Axel Heiberg Island Research Reports, McGill University, Montreal. facobsen-McGill Arctic Research Expedition 1959-1962.

Dibben, P. C. 1965. A heat-balance study on Sørbreen, Jan Mayen. Journal of Glaciology, Vol. 5, No. 42, p. 793803 .

Dumas, H. 1952-53. La méthode chimique pour la mesure du débit des cours d'eau. La Houille Blanche, $7^{\mathrm{e}}$ An., No. 5, 1952, p. 69o-701; 8e An., No. 1, 1953, p. 51-57; 8e An., No. 3, 1953, p. 360-73.

Grainger, M. E., and Lister, H. 1966. Wind speed, stability and eddy viscosity over melting ice surfaces. Journal of Glaciology, Vol. 6, No. 43, p. IOI-27.

Havens, J. M., and others. 1965. Meteorology, No. 4. Comparative meteorological survey and a short-term heat balance study of the White Glacier, Canadian Arctic Archipelago-summer 1962, [by] J. M. Havens, F. Müller and G. C. Wilmot. Axel Heiberg Island Research Reports, McGill University, Montreal. Jacobsen-McGill Arctic Research Expedition 1959-1962.

Hoinkes, H. C., and Untersteiner, N. 1952. Wärmeumsatz und Ablation auf Alpengletschern. I. Vernagtferner (Ötztaler Alpen), August i 950. Geografiska Annaler, Årg. 34, Ht. 1-2, p. 99-158.

Hubley, R. C. 1954. The problem of short period measurements of snow ablation. Journal of Glaciology, Vol. 2, No. 16 , p. $437-40$. 
Hubley, R. C. 1957. An analysis of surface energy during the ablation season on Lemon Creek Glacier, Alaska. Transactions. American Geophysical Union, Vol. 38, No. I, p. 68-85.

Keeler, C. M. ${ }^{1964 . ~ R e l a t i o n s h i p ~ b e t w e e n ~ c l i m a t e, ~ a b l a t i o n ~ a n d ~ r u n-o f f ~ o n ~ t h e ~ S v e r d r u p ~ G l a c i e r, ~ I 963, ~ D e v o n ~}$ Island, N.W.T. Arctic Institute of North America. Research Paper No. 27.

LaChapelle, E. [R.] 1959. Errors in ablation measurements from settlement and sub-surface melting. Fournal of Glaciology, Vol. 3, No. 26, p. 458-67.

Larsson, P. 1960. A preliminary investigation of the meteorological conditions on the Chamberlin Glacier. Arctic Institute of North America. Research Paper No. 2.

Mayo, L., and Péwé, T. L. 1963. Ablation and net total radiation, Gulkana Glacier, Alaska. (In Kingery, W. D., $e d$. Ice and snow; properties, processes, and applications: proceedings of a conference held at the Massachusetts Institute of Technology, February $12-16,1962$. Cambridge, Mass., M.I.T. Press, p. 633-43.)

Müller, F. 1968. Meteorology, No. 3. A high arctic climate study on Axel Heiberg Island, Canadian Arctic Archipelago summer 1961. Part II: radiation and micro-climate. Axel Heiberg Island Research Reports, McGill University, Montreal. Jacobsen-McGill Arctic Research Expedition 1959-1962.

Orvig, S. 1954. Glacial-meteorological observations on icecaps in Baffin Island. Geografiska Annaler, Arg. 36 , Ht. $3-4$, p. $193-318$.

Platt, C. M. 1966. Some observations on the climate of Lewis Glacier, Mount Kenya, during the rainy season, Journal of Glaciology, Vol. 6, No. 44, p. 267-87.

Rider, N. E., and Robinson, G. D. 1951. A study of the transfer of heat and water vapour above the surface of short grass. Quarterly Journal of the Royal Meteorological Society, Vol. 77, No. 333, p. 375-401.

Untersteiner, N. 1961 . On the mass and heat budget of Arctic sea ice. Archiv für Meteorologie, Geophysik und Bioklimatologie, Ser. A, Bd. 12, Ht. 2, p. 151-82.

Wallén, C. C. 1948. Glacial-meteorological investigations on the Kårsa glacier in Swedish Lappland, I942-1948. Geografiska Annaler, Årg. 30, Ht. 3-4, p. $45^{1-672 .}$ 